\title{
Two Examples of Modern Mosques in Sarajevo by Architect Ahmet Hadrovic
}

\author{
Ahmet Hadrovic \\ Faculty of Architecture, University of Sarajevo, Sarajevo, Bosnia and Herzegovina \\ Email address: \\ hadrovic.ahmet@gmail.com, ahmet.hadrovic@af.unsa.ba

\section{To cite this article:} \\ Ahmet Hadrovic. Two Examples of Modern Mosques in Sarajevo by Architect Ahmet Hadrovic. International Journal of Architecture, Arts \\ and Applications. Vol. 7, No. 3, 2021, pp. 87-96. doi: 10.11648/j.ijaaa.20210703.15
}

Received: August 20, 2021; Accepted: August 31, 2021; Published: September 23, 2021

\begin{abstract}
In Bosnia and Herzegovina, a relatively large number of mosques were built during the Ottoman Empire (15th19th century). During the SFRY (Socialist Federal Republic of Yugoslavia, 1945-1992), the socialist era, religion was on the margins of society, and the construction of new mosques was "in the hands" of traditional masters who followed mainly the patterns of Ottoman mosques. There are rare exceptions, such as the White Mosque in Visoko (architect Zlatko Ugljen, 1983). After the war in Bosnia and Herzegovina (1992-1995), there was a change in the social order and composition of Bosnia and Herzegovina as a state, where (now in the capitalist system) many freedoms were open, including religious ones. The construction of sacral buildings has become a "public matter of society" where architects are also involved. The author of this paper was given the opportunity to design mosques, where, as a basic approach in design, he wanted to create modern buildings that will, in addition to the basic prayer space, have a number of other contents (covering both religious and "secular" needs of people). In addition, it was a good opportunity to apply new architectural and spatial concepts, new constructions and materials in the design of mosques, as well as the aesthetics rooted in the foundations of Islam as a universal view of the world. In his designs of mosques (ten realized and several at the level of the conceptual design), the author of this paper paid special attention, in addition to "liquid functional flows", to the role of light in design, both daylight and artificial lighting.
\end{abstract}

Keywords: Bosnia and Herzegovina, Sarajevo, Modern Mosque

\section{Introduction}

With the capture of the royal city of Jajce in 1463, the Ottomans became the new masters of the area of today's Bosnia and Herzegovina. It is not without significance to point out that the Ottomans found almost completely Bogumil Bosnia, about which Vjekoslav Klaić writes in the History of Bosnia: "After the death of King Stjepan Dabiša (1395), dark days arose in Bosnia for the Catholic Church. The throne struggles and incursions of the Turks made the patorian faith unusually felt and almost prevailed in their country" [1].

In a relatively long period of time, whose basic feature is the continuity of a government, a rich cultural heritage has been achieved in which architecture has a particularly important place. Many mosques stand out in the multitude of architectural programs ${ }^{1}[2,3]$.

1Turgan Emin-beg's Mosque in Ustikolina (1448-1499, believed to be the oldest mosque in Bosnia and Herzegovina), Mosque in Kraljeva Sutjeska (1463. The mosque has a hipped roof covered with shingles, and this mosque is considered to be the oldest mosque in Bosnia and Herzegovina), Kushlat Mosque (Mosque of Sultan Mehmed II el-Fatih, Abul Feth Mosque) near Zvornik (1460-1480), Atik (Old Mosque or Sultan Suleiman Mosque) with a harem and turbe in Bijeljina (1520-1566), The White Mosque (Divan Katib Hajdar Mosque) in Sarajevo (1536-1545), the Emperor's Mosque (Sultan Bajazid Velija Mosque) in Nevesinje (1481-1512), the Emperor's Mosque (Sultan Bajezid Valije II Mosque) in Foca (1500-1501).

Dome mosques are considered a more expensive version of the mosque. Here are the domed mosques built on the territory of Bosnia and Herzegovina: Balagija's (Balagusa) mosque in Livno (1514), Mustafa Skenderpasic's (Skenderija) mosque in Sarajevo (1517), Sultan Sulejman's (Tsar's) mosque in Blagaj (1519), Ceinova (1526), Havadze Durak's (Bascarsija) mosque in Sarajevo (1528), Sinan-caus's (Dzumanusha) mosque in Livno (1529), Gazi Husrev-beg's mosque in Sarajevo (1531), Hasan-aga's (Jeni) mosque in Travnik 1549), Nezir-aga's (Aladza) mosque in Foca (1550), Kursumlija (Hadzi Bali-beg's mosque) in Kladanj (first half of the 16th century), Buzadzi hadzi Hasan's (Logavina) mosque in Sarajevo (1555), Karadjoz-Bey's Mosque in Mostar (1557), Hadim Ali-pasha's Mosque in Sarajevo (1561), Ferhad-Bey's (Ferhadija) Mosque in Sarajevo (1562), Hadzi Alija's Mosque in Pocitelj (1562), Nesuh-aga Vucjakovic's Mosque in Mostar (1564)), The Emperor's Mosque in Sarajevo (1565), the Selimija Mosque in Knezina 
The period of Austro-Hungarian rule introduced Bosnia and Herzegovina (1878-1918) into the "World of the West", a space in which man and society have a completely different view of the world, a different system of values, different architectural programs that frame individual-human and collective-social needs. In a wide range of architectural programs from this period, religious buildings also occupy a prominent place. Among the most famous are: the Franciscan monastery and the church of St. Ante Padovanski on Bistrik in Sarajevo (monastery built in 1894 according to the project of architect Carl Panek, and the church in 1912 according to the project of architect Josip pl. Vancaš), Church dedicated to the Protection of the Most Holy Mother of God in Vares (1891-1894), Church of St. Cyril and Methodius with the Theological Seminary in Sarajevo (1892-1896, architect Josip pl. Vancas), the Ashkenazi Temple in Sarajevo (19011902, architect Karlo Pařik), the Evangelical Church (today's Academy of Fine Arts) in Sarajevo (1898, architect Karlo Pařik).

The period of the Kingdom of Serbs, Croats and Slovenes (1918-1929) and the Kingdom of Yugoslavia (1929-1941) in Bosnia and Herzegovina brought completely new social relations, where for autochthonous inhabitants and religions there was no externally imposed power (occupation) but a dynamic complex of relations in which two stronger peoples (Serbs and Croats) fought for the status of "dominant" influence in Bosnia and Herzegovina.

Architectural programs reflect the continuity of general social development under the auspices of capitalism, although sacral buildings are also being built. Among the most famous sacral buildings from this period is the Church of the Most Holy Mother of God in Jajce (1930-1935).

The time of the Federal People's Republic of Yugoslavia (1945-1963) and the Socialist Federal Republic of Yugoslavia (1963-1991) is marked by socialist social relations, with a pronounced (official) departure from everything that is „national", and favoring the universal, international. All religions, including the construction of religious buildings, have been pushed to the margins of social life.

After the disintegration (1991-1995) of the joint state of SFR Yugoslavia, Bosnia and Herzegovina began a new era of its existence ${ }^{2}$. One of the important features of social life in

(1566-1567), Lala-pasha's (Beglucka or Beglek) mosque in Livno (1567), Sinanbeg Boljanic'smosque in Cajnice (1570), Mehmed-caus's mosque in Konjic (1579), Hadzi Ahmed Dukatar's (Glavica) mosque in Livno (1588), Ferhadpasha's (Ferhadija) mosque in Banja Luka (1579), Ahmed-pasha's (Carsija) mosque in Gračanica (1593), Deftedare's (Arnaudija's) mosque in Banja Luka (1594), Kzlar-aga's mosque in Mrkonjic-grad (1595), Lala-pasha's mosque in Tomislav-Grad, half of the 16th century), Jusuf-pasha's (Kursumlija) mosque in Maglaj (second half of the 16th century), Koski Mehmed-pasha's mosque in Mostar (1612), Mosque of Mehmed-pasha Kukavica in Foca (1751), Esme Sultanija's mosque in Jajce (1753), the Mosque of Hussein-Captain Gradascevic (Hussein) in Gradacac (1824), the Mosque of Azizi in Brezovo Polje (1862), the Dervish-pasha's (Poturmahalska) Mosque in Travnik (around 1863), the Mosque of Ali-pasha's Rizvanbegovic in (1848-1849), Varos mosque in Travnik (16. st.; in a great fire on September 3, 1903, the mosque burned down. During the renovation of the mosque, in 1906, a dome was built, which the building did not have in its original form), Ali-beg's in Zepce (unknown year of construction).

2 Following a referendum (March 1, 1992), in which a large majority of the this new state is the return to the national-religious identities of the three most numerous peoples in Bosnia and Herzegovina: Bosniaks (Muslims), Serbs (Orthodox) and Croats (Catholics). The construction of religious buildings within all three nations is becoming one of the most important features of this new historical epoch of Bosnia and Herzegovina.

For the Author, winning the first prize at the All-Yugoslav Architectural Competition for the Islamic Center project in Rijeka, Republic of Croatia (1991), meant entering the world of architecture, in the former Bosnia and Herzegovina and the former Yugoslavia. Regardless of the fact that the war in Croatia (1991-1995) and in Bosnia and Herzegovina (19921995) fundamentally changed the socio-political circumstances, this award opened the door to all later mosque projects done by the Author [7].

Prior to the mosques presented in this paper, the author designed three mosques, near Sarajevo [7]. In addition to being versed in Islamic architecture during his studies of architecture, the author studied mosques intensively, as an architectural program, around the world [8-17].

Following his own theory of Architecturally Defined Space (founded in 1988) [4-6], the author was interested in the specifics of mosques derived from the naturalgeographical and geographical-cultural environment, where he tried to find "the smallest common dwelling of mosques in general" and then develop that "container" in a specific natural and social environment in Bosnia and Herzegovina.

As for the Author "architecture is the framework of life" inhabited by the individual and his collectives, the mosque (and religious buildings in general) is a particularly important architectural program whose design should confirm the essence of the religion and, at the same time, send a message about universal human values and society. At the same time, the author is aware that his design "reveals" and that he himself will be the "subject of examination", both of architects and people of other professions.

\section{Adil-beg's Mosque in Sarajevo (1999)}

The Adil-beg's mosque is located along the road SarajevoVogosca-Tuzla, at the entrance to the city from the direction of Vogosca (Geographic coordinates: 435' $01.95^{\prime \prime} \mathrm{N}$, 18 23'04.84" E, Elevation: 640 m. Source: Google Earth, Accessed: 06/10/2021.), (Figure 1). On the site of this mosque stood a smaller mosque built and just opened (1989) before the war in Bosnia and Herzegovina. The minaret of this mosque (which was demolished in 1992 due to shelling)

Muslim and Croat populations voted for Bosnia and Herzegovina as an independent state, the members of the European Community recognized it (April 7, 1992) as a state. Shortly afterwards, Bosnia and Herzegovina was admitted to the United Nations (May 22nd). Croatia immediately recognized Bosnia and Herzegovina. In November 1995, an agreement was reached in Dayton (USA) between the leaders of all three peoples of Bosnia and Herzegovina (Bosniaks, Serbs and Croats), which was officially signed in Paris the following month in the presence of representatives of the UN and Western powers led by the United States. 
was designed by the author of this work, and was a hint of a new approach to the design of religious buildings.

Quite paradoxically, the project of the new mosque was done by the author in difficult war conditions in Bosnia and Herzegovina (1994). It is a facility that was supposed to provide high standards for performing prayer, along with anumber of other contents of a "secular nature". The construction of this facility was financed by various voluntary smaller and larger donations. After the basement of the building was built, the main donor (waqif) appeared, Mr. Adil-beg Zulfikarpasic, who financed most of the work until the completion and grand opening (1999) of the mosque.
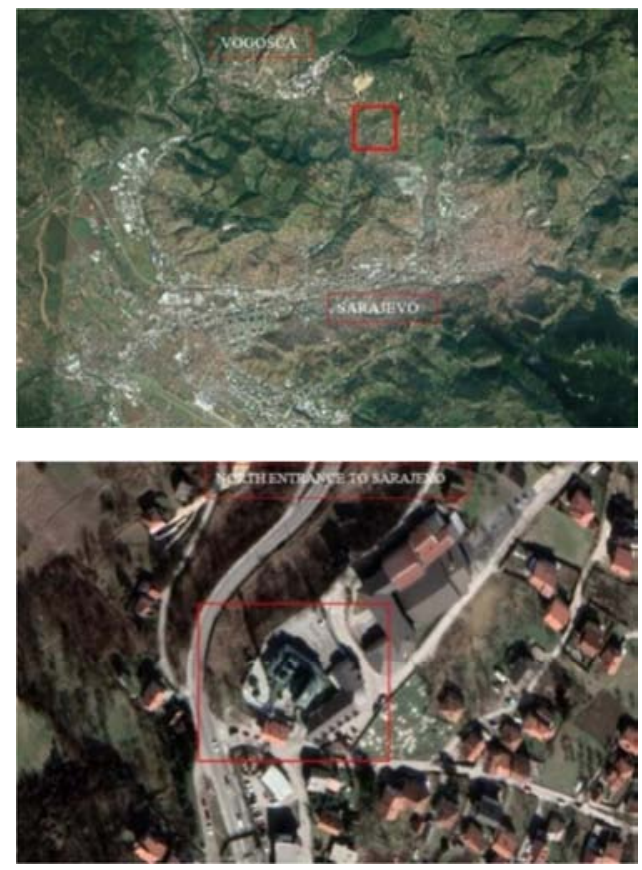

Source: Google Earth (Accessed: 06/10/2021).

Figure 1. Wider and narrower location of Adil-beg's mosque.

The project task of the new mosque, in addition to the standard spaces for this type of buildings, envisages a series of contents suitable for the "Islamic center": a multipurpose hall, a library with a hall for religious weddings and formal receptions, a classroom for religious instruction, an office.

The author initially realized that this mosque must be both extremely functional and modern, to offer a solution that could become "classic" for the design of future mosques [7]. As the "northern gate" of Sarajevo, the capital of multiethnic Bosnia and Herzegovina, its appearance should not irritate anyone, but on the contrary, to suggest a welcome [7].

The contents of this mosque are developed through the basement, ground floor and first floor (mahfil). On the ground floor level, the main harem (inner courtyard with a large gate), the central entrance to the mosque, and the main prayer area are organized. At the basement level is the "south", a side harem with a small gate and a large polyvalent hall with its own entrance party. In addition to the polyvalent hall, abdesthanas are given (designed as locker rooms that go along with modern sports halls). On the first floor there is a gallery (mahfil) and a ceremonial hall.

All the above levels of the mosque, on certain occasions, should function as a single space of the mosque [7].

One of the (unwritten) principles that the author has set before himself, when it comes to designing mosques, is that there should be no free-standing pillars in the main prayer space $^{3}$.

Ensuring the possibility of separate functioning of the mosque contents ${ }^{4}$ as well as the possibility of simultaneous use of all mosque rooms was an important input in the design of the mosque, both in defining its horizontal and vertical plan, and in designing its constructive system and, ultimately, its overall appearance.

The author ensured the efficient "internal flow" of the building with a spacious entrance part (with shelves for shoes), a hall and two staircases that connect the levels of the mosque vertically. This propulsive communication took on the character of a "change" in the intensity of the content, and in the envelope of the mosque it was solved with glass surfaces, both wall and roof (Figures 2-13).
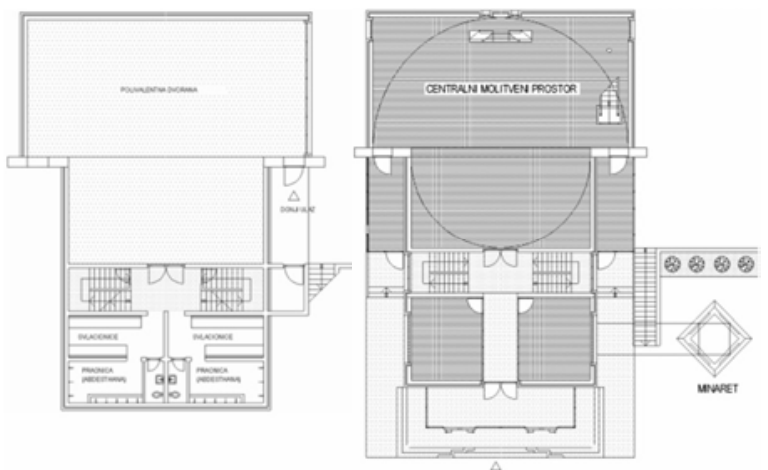

BASEMENT GROUND FLOOR
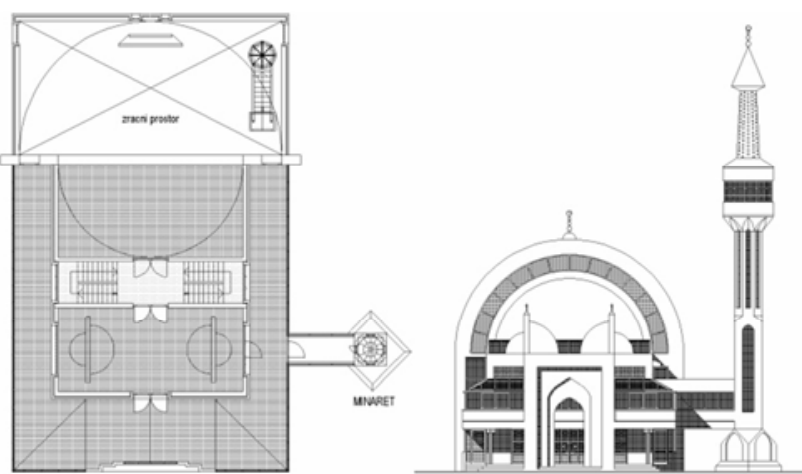

FIRST FLOORENTRANCE FACADE Source: Author

Figure 2. Foundations and entrance facade of the Adil-beg mosque.

The author paid special attention to the design of the

3 Namely, free-standing pillars disrupt the uniqueness of the prayer space and often represent an audio-visual barrier between people who are in prayer and the imam in the mihrab or on the mimber; in addition, pillars can very often disrupt the formation of rows (safs) of people in prayer, which is inadmissible from the aspect of performing collective prayer.

4This request proved to be justified in terms of ensuring the possibility of separate heating of individual rooms and functional units of the mosque. 
central dome, in addition to the necessary attention in terms of its constructive role, in terms of providing quality (uniform) natural lighting and emphasized symbolism: the combination of larger and smaller segments of the dome resulted in a light arc symbolizing the welcome ${ }^{5}$.

The author treated day and night equally in this mosque, as in all other mosques, that is, he gave light the importance of building material. During the day, light from the firmament reaches the mosque in a way that its visitor has yet to discover, while at night, light emanates from the mosque as a cheerful and encouraging sign [7].

The terrace at the level of the mahfil is a place for performing prayers, both in summer and in winter. This motif of the traditional loggia (divanhane) gained its modern meaning through the solution of the "double membrane" of the architectural object which provides interior comfort through the greenhouse effect, in winter, or intensive natural ventilation, in summer.

The minaret is designed as a spatially developed arabesque with a lot of symbolism, in which the light effects, according to a special program, suggest the significance of the events in the mosque ${ }^{6}$.
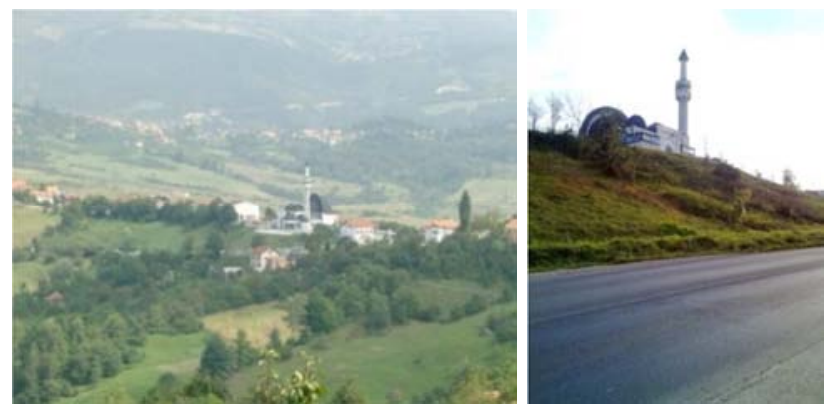

Source: Author

Figure 3. View of the Adil-beg's mosque from the west and from the north (from the road Sarajevo-Vogošća-Tuzla).

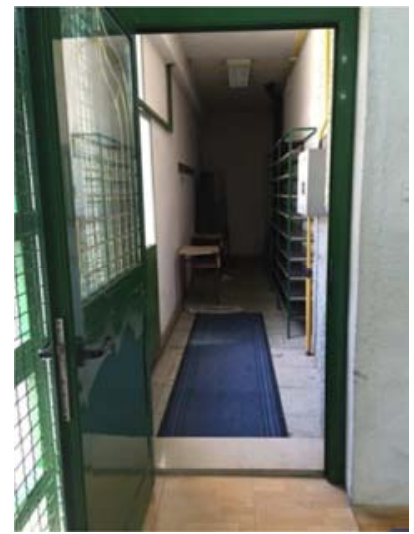

5 The author designed such a segmental dome on his first projects, the New Mosque in Solun on Krivajariver and the mosque in Tarcin. However, these first segmental domes were small in size, but noticeable enough in the overall appearance of the mosques.

6In doing so, the main association that the minaret should evoke in an outside observer is the heavenly journey of the Prophet Muhammad s.a.v.s (mirage), that is, the victory of light over darkness.
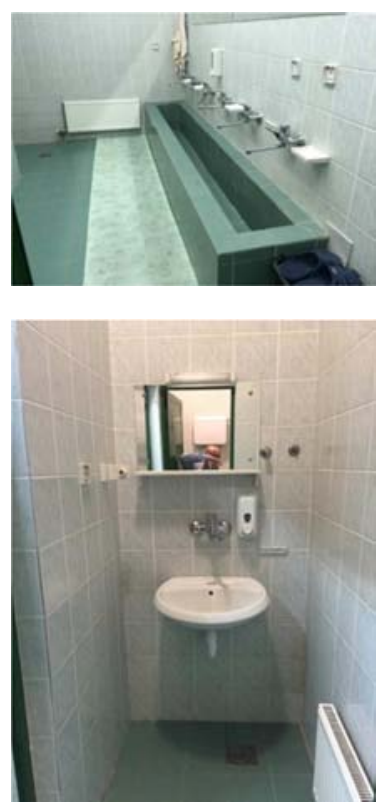

Source: Author

Figure 4. Access hall to the basement (polyvalent hall) from the lower harem of the mosque, one of two identical abdesthans and part of the sanitary block of the mosque.

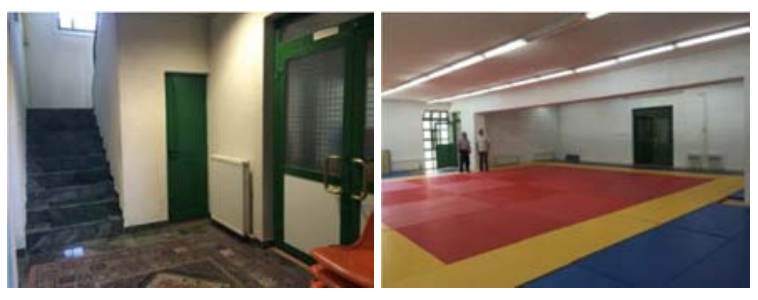

Source: Author

Figure 5. Basement-ground floor-first floor with anteroom between the sanitary block and the multipurpose hall and the multipurpose hall (in the basement of the mosque).

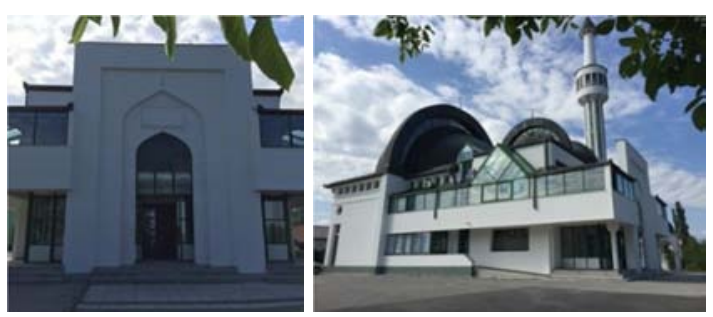

Source: Author

Figure 6. Entrance facade and view of the Adil-beg's mosque from the north.
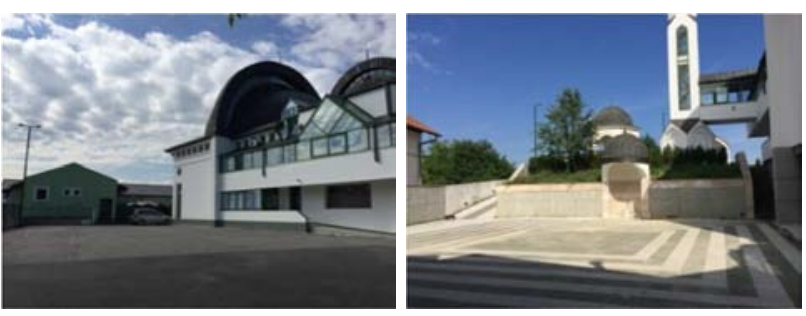

Source: Author

Figure 7. Youth Center and Musafirhana complex of the Adil-beg's mosque (view from the upper harem of the mosque), (left) and the fountain in the lower harem of the mosque (right). 

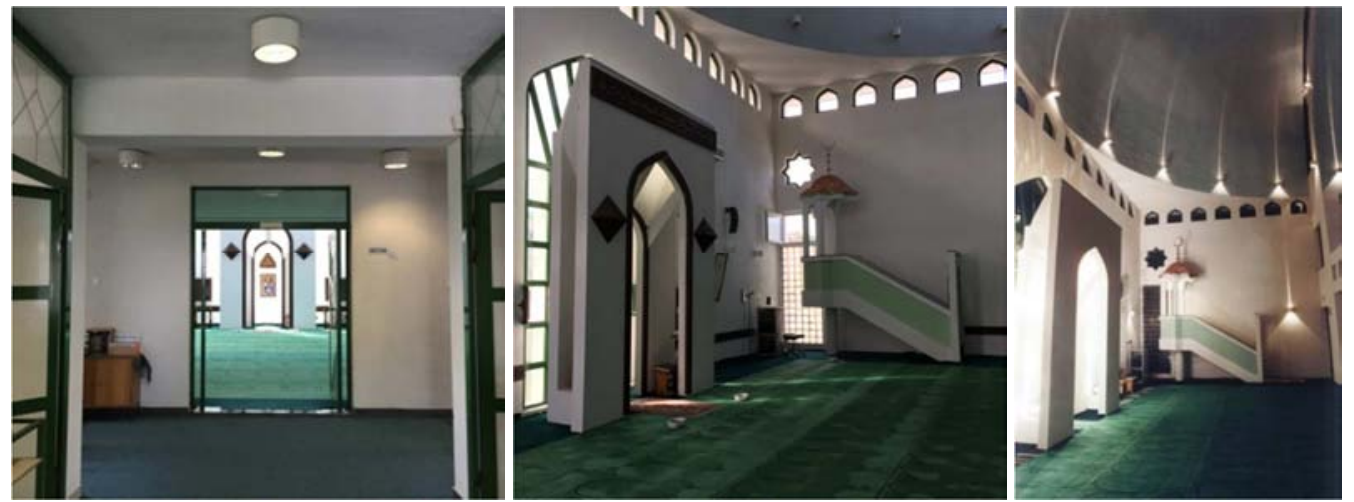

Source: Author

Figure 8. View from the entrance hall towards the interior of the mosque, mihrab and mimber (during the day) and mihrab and momber (at night).

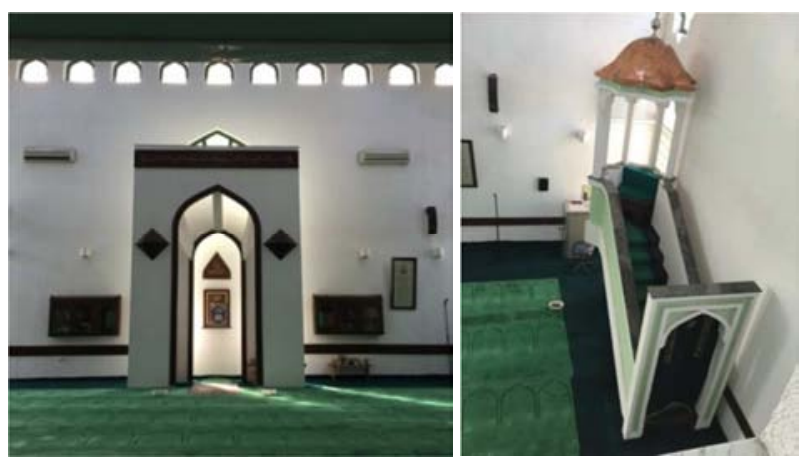

Source: Author

Figure 9. Mihrab and mimber of the Adil-beg's mosque.

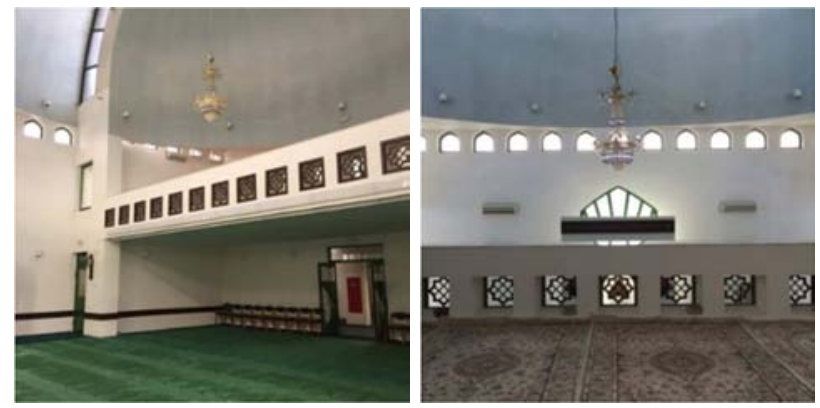

Source: Author

Figure 10. View of the mahfil from the main prayer space and the mahfil space.
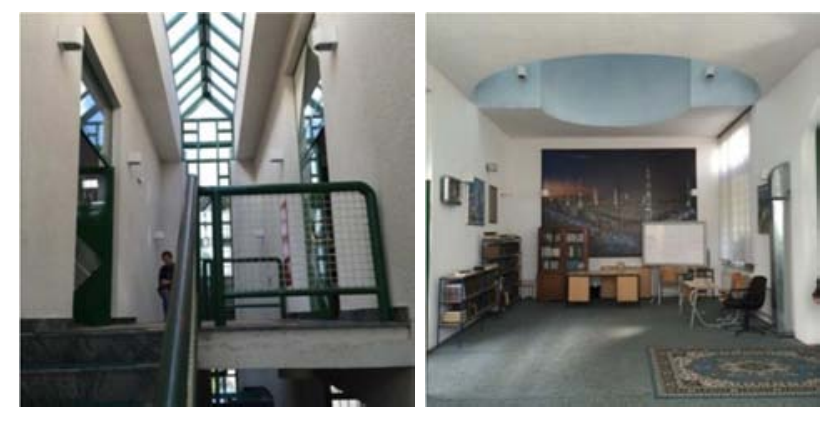

Source: Author

Figure 11. Staircase area with roof lantern and ceremonial hall (upstairs).
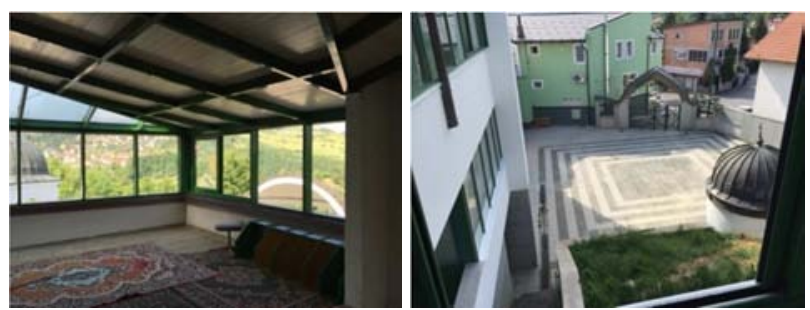

Source: Author

Figure 12. Winter garden (divanhana) and view from the divanhana to the lower harem of the mosque.
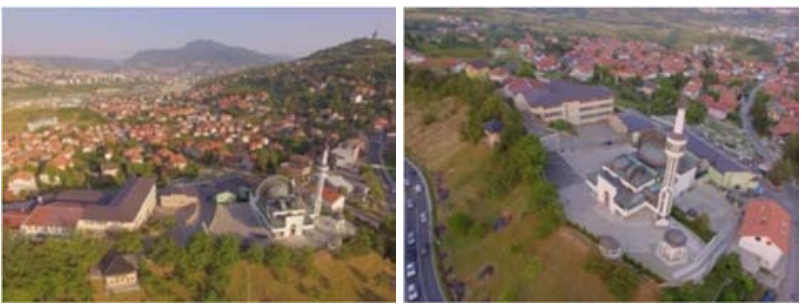

Source: Vladimir Obradovic (drone video: 07/24/2017)

Figure 13. Photos of the Adil-beg's mosque with a drone camera.
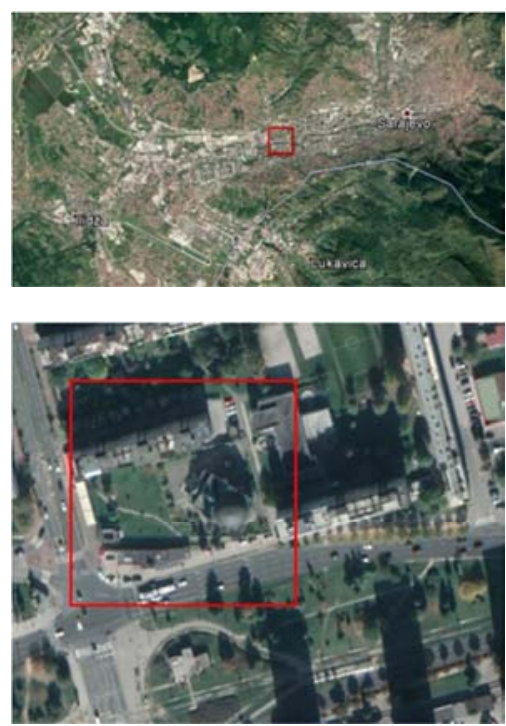

Source: Google Earth (Accessed: 06/10/2021)

Figure 14. Location of the Kuwaiti Mosque. 


\section{Kuwait Mosque in Sarajevo (2006)}

The Kuwaiti mosque is located in the Sarajevo neighborhood of Cengic Vila, along the main city road known as the "backbone" of Sarajevo (Geographic coordinates: $43^{\circ} 51^{\prime} 04.30^{\prime \prime} \mathrm{N}, 18^{\circ} 22 ' 24.56^{\prime \prime} \mathrm{E}$, Elevation: 522 m. Source: Google Earth, Accessed: 06/10/2021.). It is the location that will give great value to this mosque and make it constantly present in the everyday life of a large number of Sarajevo residents and their guests (Figure 14).

The project task of the Kuwaiti mosque in the Cengic Vila settlement in Sarajevo, in addition to the main prayer area, envisaged a number of facilities: an apartment for the imam including a garage, abdesthans and toilets (separately for men and women), a classroom for religious instruction (mekteb) mosque office and office for imams. Immediately before the construction of the building, the apartment for the imam and the entrance porch of the building were abandoned [7].
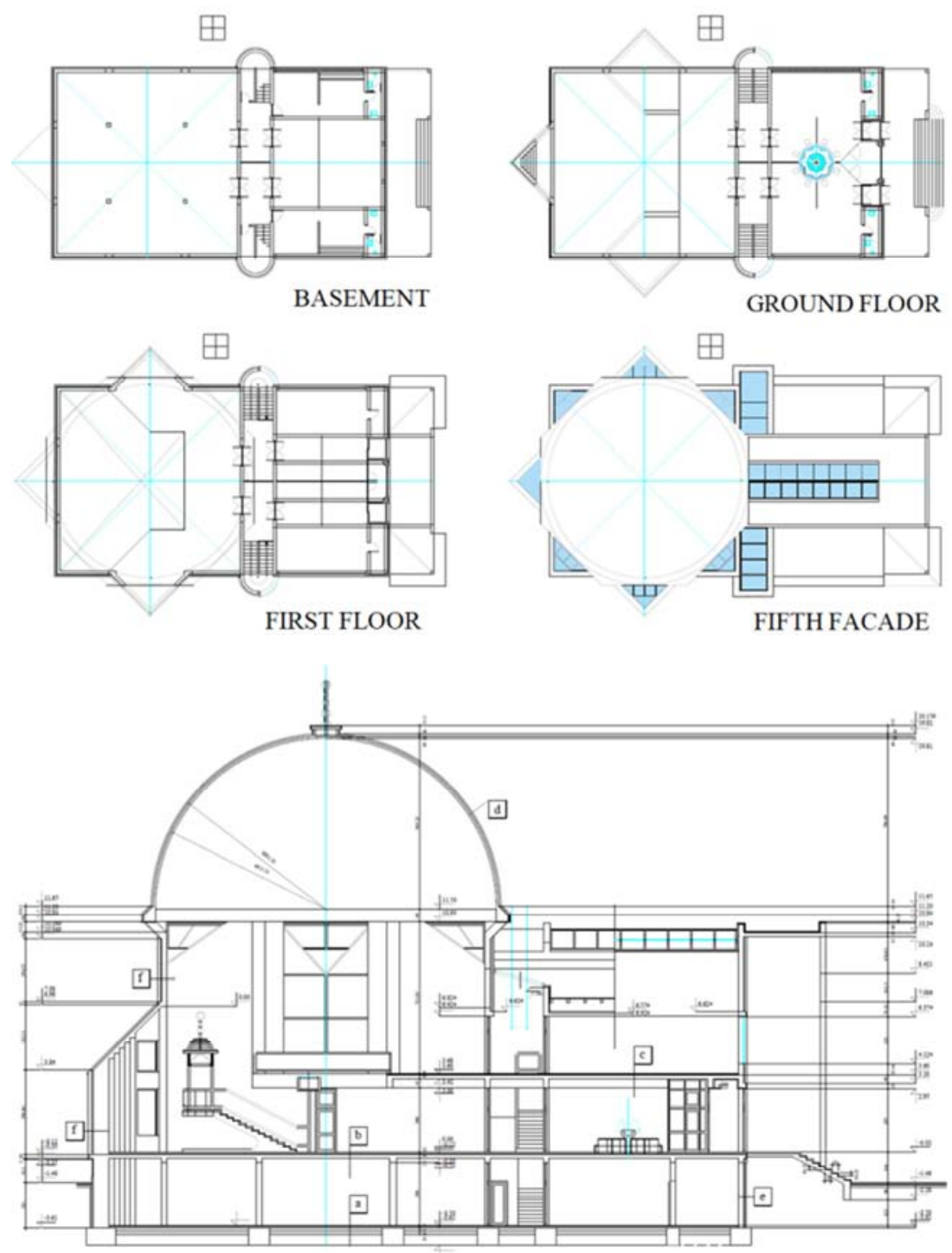

SECTION 1-1

Source: Author

Figure 15. Bases and longitudinal section of the Kuwaiti mosque.

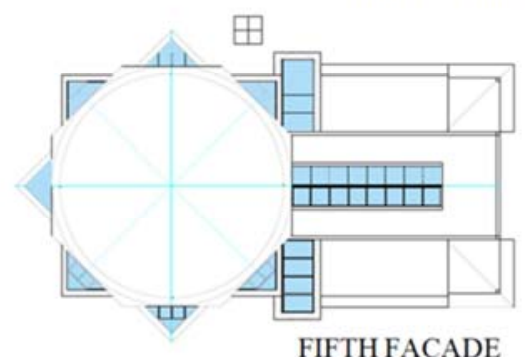

The determined groundwater level determined the level of the basement where the polyvalent hall, abdesthana and toilets were organized. On the ground floor, which is accessed by a staircase and a ramp, there is an entrance hall with abdesthans and toilets (separate for men and women) and a mosque office and an imam's office. A spacious communication with two staircases is arranged between the entrance hall and the main prayer space, symmetrically in relation to the central axis (direction of the Qibla) of the mosque. Stairs connect all the contents of the mosque vertically, from the basement to the first floor.

On the first floor of the mosque there is a gallery (mahfil) as the main prayer space for women, and a spacious classroom (mekteb) for religious instruction. Next to the classroom is a cabinet for religious teachers (mualimi). The minaret is accessed from the mahfil, over a bridge covered with a metal-glass mantle (Figures 15-27).

FIFTH FACADE 

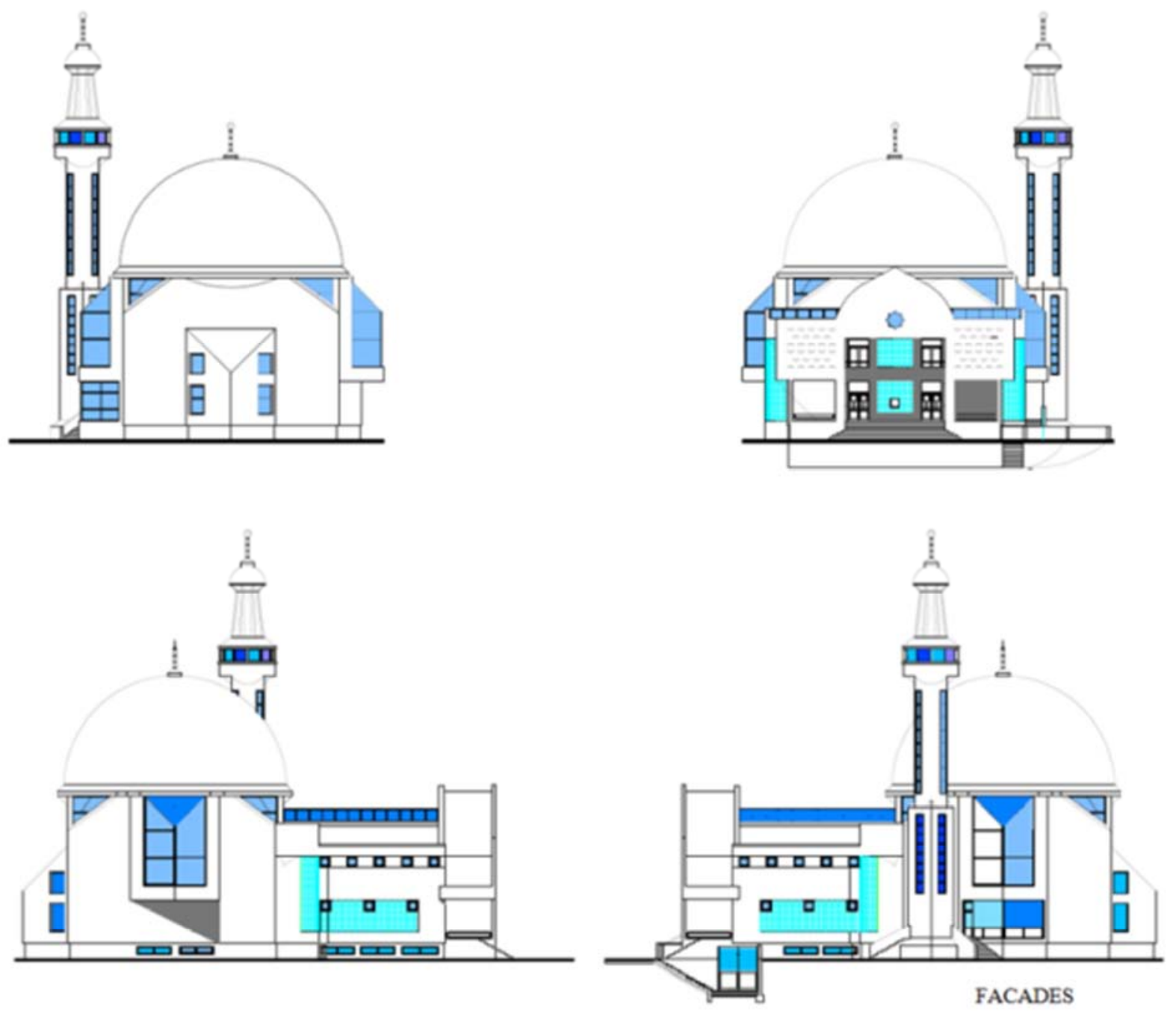

Source: Author

Figure 16. Facades of the Kuwaiti mosque.

The Kuwaiti Mosque in Sarajevo is a typical city mosque ${ }^{7}$ built right next to the main traffic longitudinal, the "backbone" of Sarajevo, in the central city zone. Designing was an extremely sensitive task given the multitude of objective and "mental" constraints imposed by the environment.

The author knew in advance that the necessary monumentality of a mosque must be achieved not by its physical size but by the power of purity and symbolism of its volumes that have their own scale, regardless of the physical structures found at the site [7].

Similar to the mosque of the Islamic Center in Novi Travnik [7], a regular eight-pointed star was used as the basis of the mosque, with the difference that all the branches of the star of the Kuwaiti mosque do not start from the same, but from different levels. Here the arms of the star became the

7The name "Kuwaiti Mosque" comes from a donation made by the Kingdom of Kuwait. The project task is defined in the Islamic Community of Bosnia and Herzegovina, and the project of the mosque was done in the company ENCO d.o.o. Sarajevo. The project managers were Messrs. Hajji-Smail Barakovac (later mutevelija of the Kuwaiti mosque) and Avdoef. Velic (later the first imam of the Kuwaiti mosque). The facility was built by ENGRA d.o.o. from Zenica. doxa of the gallery (mahfila). The shorter eight-pointed stars are visible from the interior (as "heavenly windows"), and in the fifth façade. From the interior one can see the seven (triangular) arms of the star, while the eighth (or first) arm is transformed into a longitudinal light strip that follows the main axis (direction of the Qibla) of the mosque ${ }^{8}$.
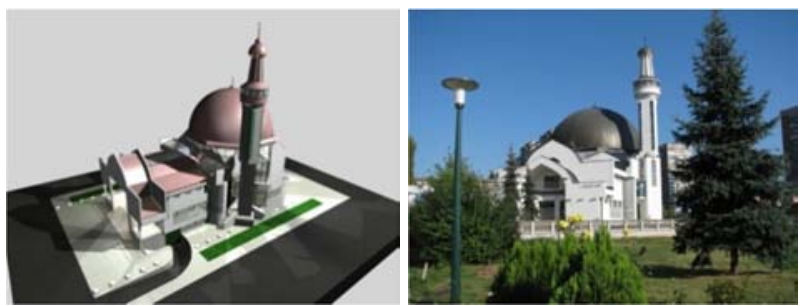

Source: Author

Figure 17. $3 D$ view of the mosque (left) and view of the mosque from the northwest (right).

8One of the author's favorite comments on the solution of the Kuwaiti mosque is the one in which the visitor of the mosque states with astonishment. "that the mosque is bigger inside than outside"! 


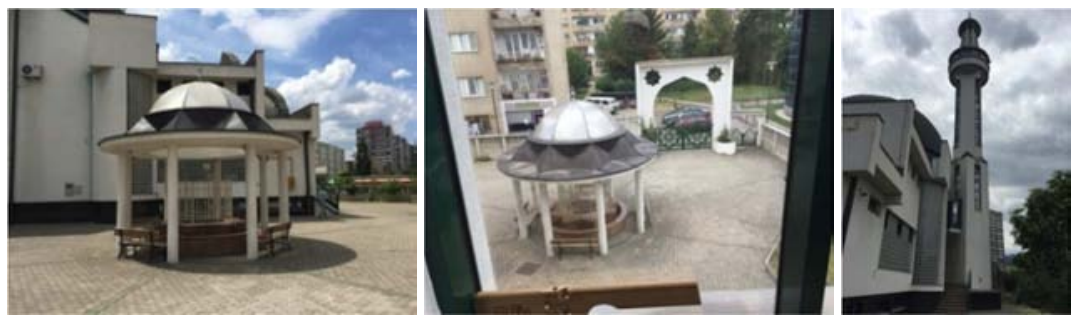

Source: Author

Figure 18. Fountain in the harem of the mosque and minaret.
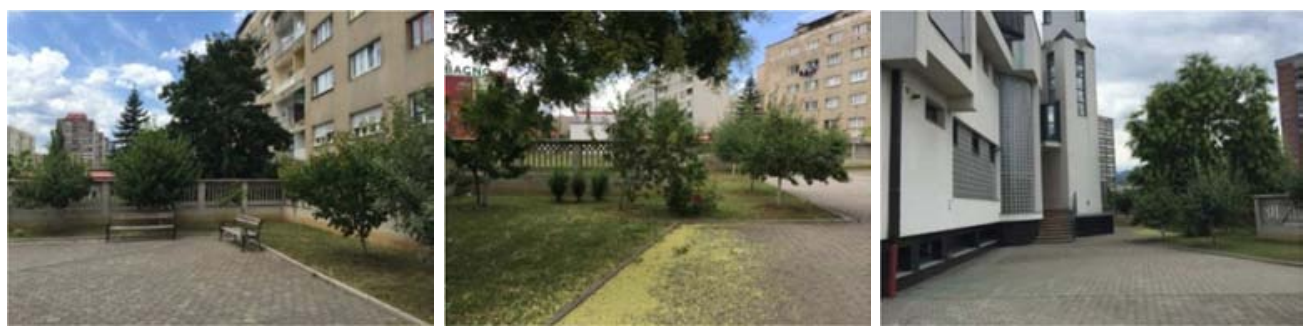

Source: Author

Figure 19. Harem of a mosque with a fruit orchard.

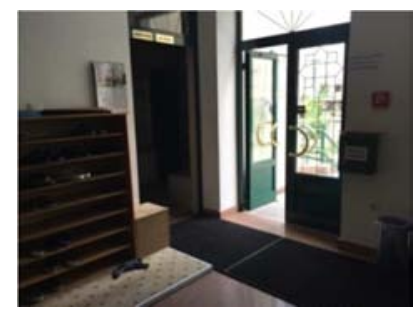

Source: Author

Figure 20. Entrance to the main hall of the mosque with shelves for shoes and abdesthana (part of the hall for men).

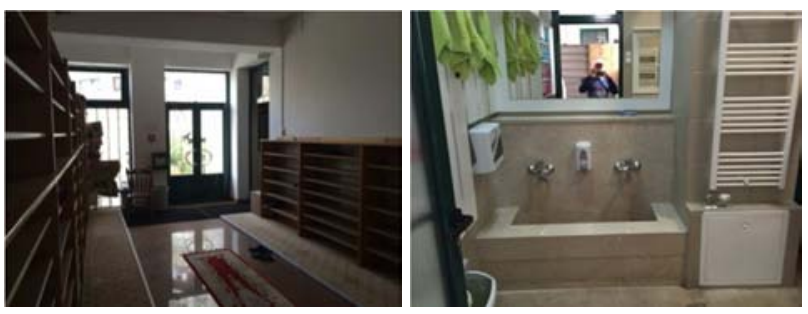

Source: Author

Figure 21. Entrance to the main hall of the mosque with shelves for shoes and abdesthana (part of the hall for women).
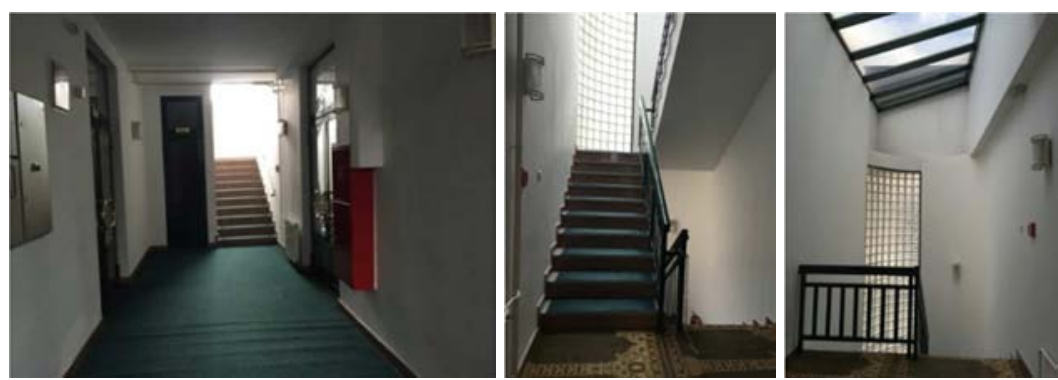

Source: Author

Figure 22. Hall with a staircase between the polyvalent hall and the abdesthana in the basement (left), one of the two staircases symmetrically placed in relation to the central axis of the kobli mosque (in the middle) and the roof lantern in the staircase (right).
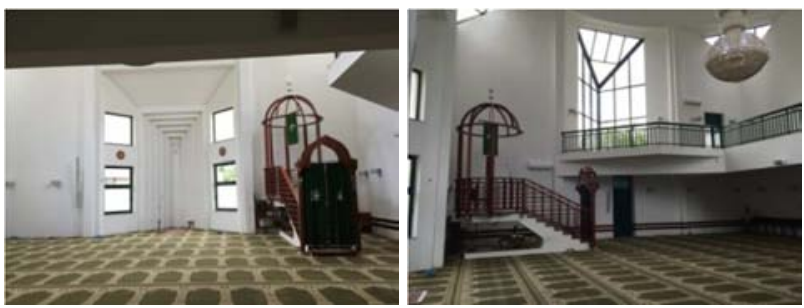

Source: Author

Figure 23. Mihrab and mimber (left) and mimber and mahfil (right).
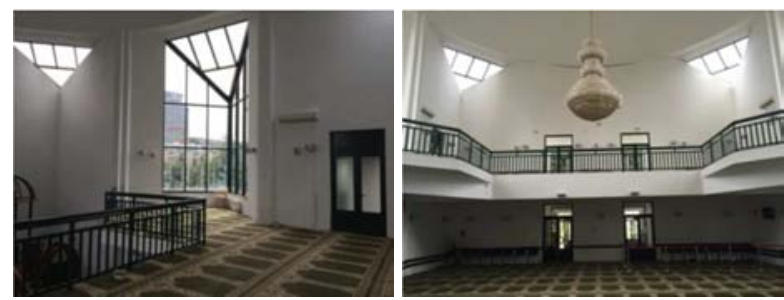

Source: Author

Figure 24. Mahfil space (left) and view of the mahfil from the direction of the mihrab. 


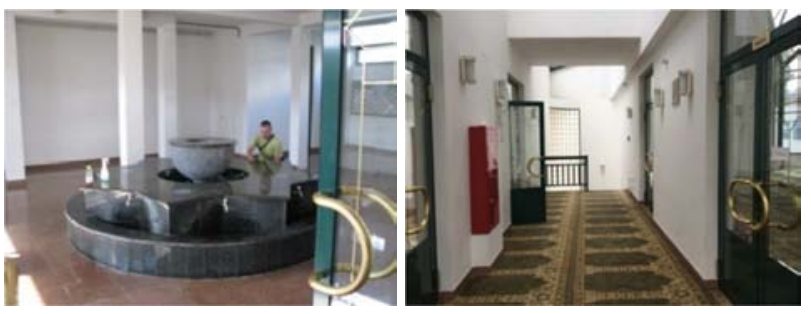

Source: Author

Figure 25. Abdesthan in the basement area (left) and the hall with a staircase upstairs, between the mahfil and the classroom (right).

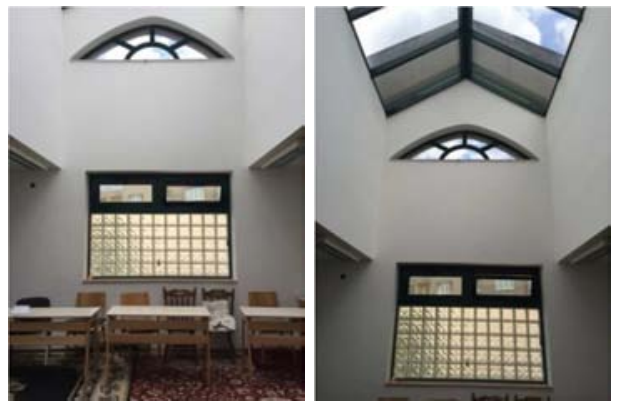

Source: Author

Figure 26. Classroom (upstairs) with a roof lantern.
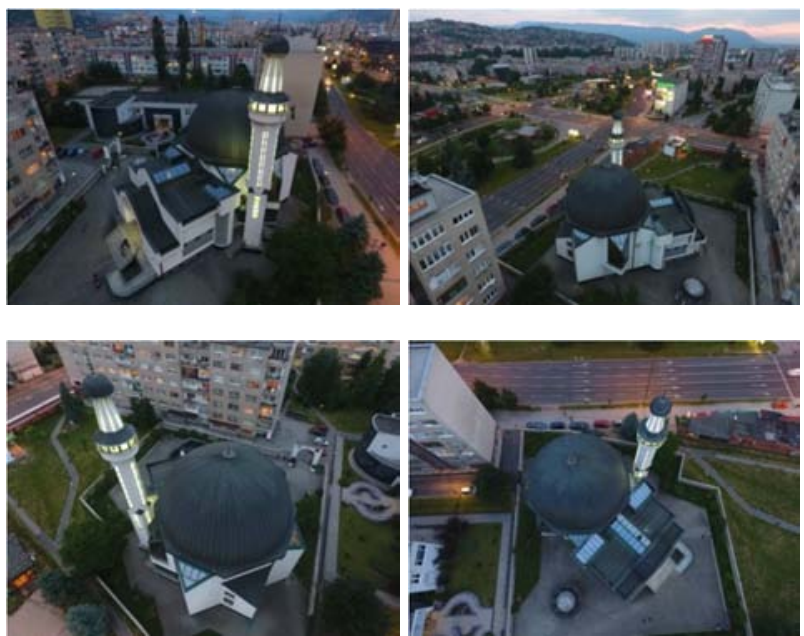

Source: Klix-drone (drone video: 07/20/2017)

Figure 27. Photos of the Kuwaiti mosque by drone camera.

\section{Conclusion}

"Carrying a deep-seated fundamental sense of all that the symbolism of the mosque's 'architectural language' expresses in its own design endeavor, the author himself, through his own professional experience, through realized and unrealized mosque projects, not only clearly testified to that feeling. rather, he translated it into his own hermeneutics of 'mosque space', a hermeneutics that not only brings freshness and inspiration to the modern language of Islamic sacred architecture, but also offers an irresistibly likable, unobtrusive design of mosque space as a public space in which the human being lives and works. dialogue, multiculturalism and as only God's polish on the face of the macrocosm, whose domed vault embraces the entire human civilization and unselfishly opens itself to every view that rises with longing towards it" ${ }^{\prime 9}$ [7].

Religion is a form of consciousness that has been an integral part of the individual man and his communities since its inception. She changed her form and content, but she always assumed that a man would respect something that was "above him." According to the Bosnian-Herzegovinian society (which is highly multiethnic and multi-religious), the author of this paper (and the author of the mosque designs presented here) was aware of the responsibility that the "mosque is God's house" in which man (believer) should experience an atmosphere of "obedience to God". "And a sense of 'privilege to be there.' The design of the mosque should put "earthly wealth", "the wealth of its donor", in the background, emphasizing the universal idea of good in people. The author wanted to create such a design of mosques that will attract members of Islam as a place to pray, as well as all people (regardless of their religion, gender, ethnicity.) because of their attractive symbolism expressed in the language of architecture.

\section{References}

[1] Klaic, V. (1990), Povijest Bosne, fototip izdanja iz 1882. god., Svjetlost, Sarajevo.

[2] Pasic, A. (1994), Islamic Architecture in Bosnia and Hercegovina, IRCICA, Istanbul.

[3] Redzic, H. (1983), Studije o islamskoj arhitektonskoj bastini, Veselin Maslesa, Sarajevo.

[4] Hadrovic, A. (2007), Defining Architecrural Space on the Model of the Oriental StyleCity House in Bosnia and Herzegovina, Serbia, Montenegro, Kosovo and Macedonia, Booksurge, LLC, North Charleston, SC, USA.

[5] Hadrovic, A. (2009), Structural Systems in Architecture, Booksurge, LLC, North Charleston, SC, USA.

[6] Hadrovic, A. (2008.), Bioclimatic Architecture, Searching for a Path to Heaven, Booksurge, LLC, North Charleston, SC, USA.

[7] Hadrovic, A. (2017), Moj pristup projektiranju dzamija, Arhitektonski fakultet Univerziteta u Sarajevu.

[8] Ünsal, B. (1959), Turkichislamic Architecture, London.

[9] Oto-Dorn, K. (1971), Islamska umetnost, Biblioteka "Umetnost u svetu", Bratstvojedinstvo, Novi Sad.

[10] Alic, H. S. (1976), Arapsko-islamska filozofija; definicija i znacaj $u$ istoriji, Orijentalniinstitut u Sarajevu, POF XXIV/1974., Sarajevo.

[11] Grozdanic, Dr S. (1976), Uvod u arapsko-islamsku estetiku, Orijentalni institut uSarajevu, POF XXIV/1974., Sarajevo.

[12] Grabar, O. and others (2007), Islam. Art and Architecture, the American University in Cairo Press.

9 Prof. Dr. Resid Hafizovic, excerpt from the book review: Hadrovic, A. (2017), Moj pristup projektiranju dzamija (My approach to designing mosques), Faculty of Architecture in Sarajevo (p. ii). 
[13] Frishman, M., Khan, H. U. (1994), The Mosque: History, Architectural Development \&Regional Diversity, Thames \& Hudson, London.

[14] Petruccioli, A. (2007), After Amnesia, Learning from The Islamic Mediterranean Urban Fabric, ICAR, (C) Attilio Petruccioli.

[15] Mustafa, S. (2015), Baghdad University Design (Baghdad
University Mosque by WalterGropius), South Dakota State University, Department of Architecture.

[16] Uluhanli, L. (2017), Mosques: Splendors of Islam, Rizzoli; Illustrated edition.

[17] O'Kane, B. (2019), Mosques: The 100 Most Iconic Islamic Houses of Worship, Assouline, New York. 